\title{
Energy Values of Orchardgrass Hay for Growing Calves
}

\author{
Junjiro Sekine, Ziro Morita, Ryozo OURA \\ and Yasushi Asahida* \\ Department of Animal Science, Faculty of Agriculture, \\ Tottori University, Tottori-shi 680 \\ * Animal Science Department, Faculty of Agriculture, \\ Hokkaido University, Sapporo-shi 060
}

(Received June 23, 1988)

\begin{abstract}
Digestible, metabolizable and net energy values for orchardgrass hay harvested at the first defoliation (1st cut) and regrowth (2nd cut) were evaluated in order to obtain information on the nutritive values of a diet for growing calves. Metabolism trials were carried out with 6-mo.-old castrated male calves. The results obtained were as follows: 1) There were no significant differences in mean digestibilities of dry matter, organic matter, cellular contents and acid detergent fiber between 1st and 2nd cut hay. 2) Crude protein, cell wall constituents and hemicellulose in 2nd cut hay were significantly more digestible than those in 1st cut hay. 3) Energy digestibility was significantly correlated with digestibilities of dry matter, organic matter, cellular contents and crude protein. The metabolizability of energy was also significantly correlated with energy digestibility. 4) Net energy for growth was estimated to be $0.73 \mathrm{MJ} / \mathrm{kg} \mathrm{DM}$ and $1.28 \mathrm{MJ} / \mathrm{kg} \mathrm{DM}$ for the 1st and 2nd cut hay used in the present study.
\end{abstract}

Jpn. J. Zootech. Sci., 60 (3) : 286-291, 1989

Key words : Energy value, Orchardgrass hay, Digestibility, Metabolizability, Calf

In 1987, the Japanese National Research Council revised the feeding standards for beef cattle. The energy value of a feedstuff has been evaluated by the total digestible nutrients (TDN) in the standard ${ }^{1)}$. The standard, however, has considered that metabolizable energy (ME) is more accurate in evaluating the energy for animal production than TDN or digestible energy (DE) ${ }^{1)}$. Net energy (NE) has been recognized as the most theoretical evaluation of energy in feeds ${ }^{1}$. Net energy is calculated either by subtracting heat increment from $\mathrm{ME}$ or by multiplying the efficiency of utilization of $\mathrm{ME}(k)^{1,2}$. The energy units of ME and NE have been adopted by the feeding standards in the United Kingdom and the United States, while it is not possible to do so in Japan because conditions here make it difficult to adopt the ME or NE system due to less available information on ME or NE values of feeds produced in this country.

It is well recognized that evaluation of feed by $\mathrm{ME}$ with $k$ or NE makes it possible to formulate a ration suitable to economical animal production from the viewpoint of its adaptability to the practical farming business ${ }^{11}$. Thus, the feeding standard in this 
country may have to adopt the ME or NE system in the near future. To accomplish this, it is necessary to accumulate information on the ME or NE values of feedstuffs produced in Japan.

The purpose of the present study is to evaluate energy values of orchardgrass hay harvested at the first defoliation or regrowth for growing calves.

\section{Materials and Methods}

The animals used were 6-mo.-old Holstein castrated male calves. They were kept in individual crates. Thirteen calves were divided into 2 groups ; 7 in one group and 6 in the other. The group with 7 calves was voluntarily fed orchardgrass hay 1 st cut at the late bloom stage without concentrate supplementation, while the other group was fed 2nd cut orchardgrass hay. The 14 day total experimental period consisted of 7-day preliminary and 7-day comparison periods. The trial for a 24-hour respiratory measurement was carried out on the last day of the comparison period using an open-circuit ventilated head hood ${ }^{3)}$. Feed, feces, urine and feed refusal were measured daily in the comparison period. A ten percent aliquot of feces, urine and any refusal were composited weekly for laboratory analysis. Urine was acidified with sulfuric acid to avoid the loss of nitrogen.

Proximate analyses were done via the methods of A.O.A.C. ${ }^{4)}$ on feed, feces, urine and feed refusal. Fractions of detergent fiber were determined via the method presented by GoERING and VAN SoEST ${ }^{5)}$. Gross energy (GE) values were measured using an adiabatic bomb calorimeter. Samples of urine were lyophilized before the measurement of GE. Statistical analyses were made via the methods described by SNEDECOR ${ }^{6}$.

\section{Results}

Table 1 shows the chemical composition and GE value of orchardgrass hay. Contents of dry matter (DM), organic matter (OM) and GE were about the same in both hays with a tendency to be a little greater in GE of 2nd cut hay. Crude protein (CP) content was higher in 2nd cut hay than in 1st cut hay, while 1st cut hay contained greater fiber fractions such as crude fiber (CF), cell wall constituents (CWC), acid detergent fiber (ADF) and acid detergent lignin (ADL). Hemicellulose, however, was

Table 1. Chemical composition of orchardgrass hay fed to growing calves

\begin{tabular}{|c|c|c|c|c|c|c|c|c|c|c|c|c|}
\hline Hay & $\mathrm{DM}^{12}$ & $\mathrm{OM}$ & $\mathrm{CP}$ & $\mathrm{EE}$ & NFE & $\mathrm{CF}$ & Energy & $\mathrm{CC}$ & CWC & $\mathrm{ADF}$ & $\begin{array}{l}\text { Hem } \\
\text { cellulo }\end{array}$ & $\mathrm{AD}$ \\
\hline & 96 & & 1 & A & & $\mathrm{M}$ & $\mathrm{kgDM}$ & & & $96 \mathrm{DM}$ & & ב \\
\hline & 84.4 & 91.8 & 8. 8 & 1. & & 37.9 & & 30.9 & 69. I & 45.4 & 23.7 & 6.2 \\
\hline 2nd cut & 81.9 & 90.4 & 12.7 & 2.4 & 42.2 & 33. 1 & 18.2 & 32.1 & 67.9 & 41.6 & 26.3 & 4. 5 \\
\hline
\end{tabular}

1) Abbreviations are : $\mathrm{DM}$; dry matter, $\mathrm{OM}$; organic matter, $\mathrm{CP}$; crude protein, EE ; ether extracts, NFE; nitrogen free extracts, CF; crude fiber, CC; cellular contents, CWC; cell wall constituents, ADF ; acid detergent fiber, and ADL; acid detergent lignin. 
contained at a higher level in 2nd cut hay than in 1st cut hay.

Mean coefficients of digestibility of nutrients with standard deviation are shown in Table 2 together with live weight and daily dry-matter intake (DMI). There were neither significant differences in live weight and DMI between either group nor different digestibilities of DM, OM, cellular contents $(\mathrm{CC})$ and $\mathrm{ADF}$ between 1st and 2nd cut hay. The digestibility of CP was significantly higher in 2nd cut hay than in 1st cut hay $(\mathrm{P}<0.01)$. The CWC and hemicellulose in 2 nd cut hay were significantly more digestible than those in 1 st cut hay $(\mathrm{P}<0.01)$.

The digestibility and metabolizability of GE showed no significant difference between either hay (Table 3). Analyses of correlation revealed that there were significant correlations between the digestibility of GE and those of DM, OM, CC and CP. Regression analyses of GE digestibility (GED) on DM, OM, CC and CP digestibilities (DMD, OMD, CCD and $\mathrm{CPD}$, respectively, \%) resulted in the following equations :

$$
\begin{aligned}
& \text { GED }(\%)=0.93( \pm 0.16) \mathrm{DMD}+0.52, \mathrm{r}=0.858, \mathrm{P}<0.01, \text { s.e. } \pm 0.5 \\
& \text { GED }(\%)=0.95( \pm 0.19) \mathrm{OMD}-2.94, \mathrm{r}=0.831, \mathrm{P}<0.01, \text { s.e. } \pm 0.5 \\
& \text { GED }(\%)=0.31( \pm 0.08) \mathrm{CCD}+35.2, \mathrm{r}=0.745, \mathrm{P}<0.01, \text { s.e. } \pm 0.6 \\
& \text { GED }(\%)=0.29( \pm 0.11) \mathrm{CPD}+36.8, \mathrm{r}=0.612, \mathrm{P}<0.05, \text { s.e. } \pm 0.7
\end{aligned}
$$

\begin{tabular}{|c|c|c|c|c|c|c|c|c|c|}
\hline & $\mathrm{DM}^{1)}$ & $\mathrm{OM}$ & $\mathrm{CP}$ & $\mathrm{CC}$ & CWC & $A D F$ & $\begin{array}{l}\text { Hemi - } \\
\text { cellulose }\end{array}$ & $\begin{array}{r}\text { Live } \\
\text { weight }\end{array}$ & DMI \\
\hline & & & & $\%$ & & & 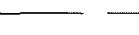 & $-\mathrm{kg}$ & - \\
\hline \multirow[t]{2}{*}{1 st cut } & 53.7 & 56.1 & 44.3 & 55.5 & 52.9 & 47.2 & 62.3 & 162 & 3. 32 \\
\hline & 2.4 & 2.1 & 5.0 & 6. 2 & 1.2 & 2.2 & 2. 8 & 6 & 0.17 \\
\hline 2 nd cut & 55.6 & 58.1 & 54.5 & 47.3 & 60.4 & 51.9 & 73.9 & 169 & 3. 41 \\
\hline S.D. & 3.7 & 3.6 & 4. 9 & 8.5 & 3.9 & 5.0 & 3.6 & 10 & 0.16 \\
\hline \multicolumn{10}{|l|}{ Statistical } \\
\hline $\begin{array}{l}\text { Significance } \\
\text { between diets }\end{array}$ & $N S^{2}$ & NS & $\mathrm{P}<0.01$ & NS & $\mathrm{P}<0.01$ & NS & $\mathrm{P}<0.01$ & NS & NS \\
\hline
\end{tabular}

Table 2. Mean digestibility with standard deviation of nutrients in 1st and 2nd cut orchardgrass hay fed to growing calves together with live weight and dry-matter intake (DMI) per day

1) Abbreviated notations are the same as Table 1.2) Not significant

Table 3. Digestibility and metabolizability of gross energy in 1st and 2nd cut orchardgrass hay fed to growing calves

\begin{tabular}{cccc}
\hline \hline \multicolumn{2}{c}{ Orchardgrass } & Digestibility & Metabolizability \\
\hline 1st cut hay Mean & 0.510 & 0.443 \\
& S. D. & 0.023 & 0.014 \\
2nd cut hay Mean & 0.515 & 0.449 \\
& S. D. & 0.046 & 0.086 \\
\hline
\end{tabular}


Table 4. Energy values of orchardgrass hay measured in the present study together with those presented by Church (1986)

\begin{tabular}{|c|c|c|c|c|c|c|}
\hline Orchardgrass hay & $\mathrm{DE}^{11}$ & $\mathrm{ME}$ & $\mathrm{NEg}$ & $\mathrm{CP}$ & $\mathrm{CF}$ & Source \\
\hline & \multicolumn{3}{|c|}{$\mathrm{MJ} / \mathrm{kg} \mathrm{DM}$} & - & H- & \\
\hline I st cut & 9.0 & 7.8 & 0.73 & 8.8 & 37.9 & Present study \\
\hline 2 nd cut & 9.4 & 8.2 & 1. 28 & 12.7 & 33.1 & Present study \\
\hline Early bloom stage & 10.9 & 9.1 & 2.59 & 11 & 34 & Church (1986) \\
\hline Late bloom stage & 9.2 & 7.5 & 1.17 & 8 & 37 & Church (1986) \\
\hline
\end{tabular}

1) Abbreviated notations are shown in the context.

There were no significant correlations between GED and the digestibility of fibrous materials.

The regression analysis of metabolizability of GE $(q)$ on GED resulted in the following equation :

$$
q=0.93( \pm 0.03) \mathrm{GED} / 100-0.04, \mathrm{r}=0.997, \mathrm{P}<0.01 \text {, s.e. }<0.001 \text {. }
$$

Contents of digestible and metabolizable energy (DE and $\mathrm{ME}$ ) in hay were calculated using the digestibility and metabolizability measured in the present study. The amount of $\mathrm{NE}$ for growth (NEg) in hay was estimated using the ME for maintenance presented by SEKINE et al. ${ }^{7)}$ and heat production measured in the present study. The values of $\mathrm{NEg}$ averaged $0.73 \pm 0.21 \mathrm{MJ} / \mathrm{kg} \mathrm{DM}$ and $1.28 \pm 0.34 \mathrm{MJ} / \mathrm{kg} \mathrm{DM}$ for 1st and 2nd cut hay as shown in Table 4 together with DE and ME values. The amount of NEg in 2nd cut hay was significantly greater than that in 1st cut hay $(\mathrm{P}<0.05)$.

\section{Discussion}

Chemical compositions of orchardgrass hay used in the present study were similar to those presented by $\mathrm{CHURCH}^{8)}$. The quality of hay in the present study, judged by chemical composition, was inferior to that presented by the Japanese Feeding Standard for Beef Cattle ${ }^{1)}$. The digestibility of CP was significantly higher in 2nd cut hay than in 1 st cut hay. SEKINE et al. ${ }^{9}$ showed that a ration containing a higher level of $\mathrm{CP}$ had a greater digestibility of CP. FURUYA and TAKAHASH ${ }^{10)}$ studied the relationship of $\mathrm{CP}$ content in a diet to its apparent digestibility, and revealed that the effect of the quantity of metabolic fecal nitrogen on the content of $\mathrm{CP}$ caused the difference in apparent digestibility of $\mathrm{CP}$ of diets containing different levels of CP. Thus, the lower content of $\mathrm{CP}$ was inferred to be responsible for a lower digestibility of $\mathrm{CP}$ in 1st cut hay than in 2nd cut hay. A significant difference in CWC digestibility between both hays appears to be explained by the digestibility of hemicellulose which was calculated by subtracting ADF from CWC, because ADF digestibility did not differ significantly between the hays. The difference in hemicellulose content or the difference in the quality of hemicellulose between 1st and 2nd cut hays may have caused the difference in hemicellulose digestibility. However, the absence of direct knowledge on the relationship between content and digestibility of hemicellulose or the quality of 


\section{Sekine, Morita, OURA and Asahida}

hemicellulose of 1st and 2nd cut hay left us unable to clarify why the digestibility of hemicellulose in 2 nd cut hay was greater than in 1st cut hay.

The direct determination of $\mathrm{ME}$ content in roughage and $k$ require much time and laborious work on the metabolism trial. Thus, it may be convenient that the estimation of $\mathrm{DE}$ and $\mathrm{ME}$ content in roughage is possible from the results of the digestion trial. The regression analyses revealed that the digestibility of GE may be estimated from the digestibility of DM or OM with fairly high accuracy. Then the metabolizability may be estimated from the energy digestibility with high accuracy. Using these estimates, the evaluation of energy values of roughage may be made with much less time and less laborious work. More work, however, is required to clarify the relationship between the results of the metabolism trial and digestion trial.

A comparison of energy values for orchardgrass hay with the relevant values presented by $\mathrm{CHURCH}^{8)}$ revealed that energy values of 1st and 2nd cut hay in the present study were inferior to the relevant values for hays harvested at late and early bloom stage with about the same contents of CP and crude fiber ${ }^{8)}$ (Table 4). The hay in the present study contained about half the NEg values presented by $\mathrm{CHURCH}^{8)}$. The ratio of NEg content was about 2: 1 in early and late bloom orchardgrass hay ${ }^{8)}$. The ratio of NEg content for 2 nd and 1st cut hay was also about $2: 1$ in the present study. Thus, the energy value of hay in the present study may have differed from those values presented by $\mathrm{CHURCH}^{8)}$ because of the estimating technique.

It was concluded that orchardgrass hay used in the present study contained $9.0 \mathrm{MJ}$ $\mathrm{DE} / \mathrm{kg} \mathrm{DM}, 7.8 \mathrm{MJ} \mathrm{ME}$ and $0.73 \mathrm{MJ} \mathrm{NEg}$ for 1st cut hay harvested at the late bloom stage, and 9.4 MJ DE, 8.2 MJ ME and 1.28 MJ NEg for 2nd cut hay at the vegetation stage.

\section{References}

1) National Research Council of Agriculture, Forestry and Fisheries, Japanese Feeding Standard for Beef Cattle. 47-48. N.R.C. MAFF. Tokyo. 1987.

2) Agricultural Research Council, The Nutrient Requirements of Ruminant Livestock. 109-118. Commonwealth Agricultural Bureaux. Slough. 1980.

3) Sekine, J., S. Morita, T. Morooka, S. Kondo, M. Okubo and Y. Asahida, Jpn. J. Zootech. Sci., $56: 787-791.1985$.

4) Association of Official Analytical Chemists, Official Methods of Analysis. 11th ed. 122-131. A.O.A.C. Washington DC. 1970.

5) Goering, G.W. and P.J. Van Soest, Agriculture Handbook No. 379. 1-20. USDA. Washington DC. 1970.

6) Snedecor, G.W., Statistical Methods. 5th ed. 85-92. and 122-193. The Iowa State Univ. Press. Ames. 1966.

7) Sekine, J., S. Morita, T. Morooka, S. Kondo, M. Okubo and Y. Asahida, Jpn. J. Zootech. Sci., 56 : 920-924. 1985.

8) Church, D.C., Livestock Feeds and Feeding. 2nd ed. 480. Prentice-Hall. Englewood Cliffs. 1986.

9) Sekine, J., S. Kondo, M. Okubo and Y. Asahida, J. Fac. Agr. Hokkaido Univ., 62 : 349-353. 1986.

10) Furuya, S. and S. Takahashi, Jpn. J. Zootech. Sci., 50 : 790-795. 1979. 


\title{
発育中の子牛に対するオーチャードグラス乾草のエネルギー価
}

\author{
関根純二郎・森田二郎・大浦良三・朝日田康司 ${ }^{*}$ \\ 鳥取大学農学部, 鳥取市 680 \\ * 北海道大学農学部, 札幌市 060
}

オーチャードグラス 1 番刈りおよび2 番刈り乾草につ いて，発育中の子牛の飼料としてのエネルギー価評価の ため，可消化エネルギー，代謝エネルギーおよび正味エ ネルギー価を查定した，6力月齢のホルスタイン種去勢 雄子牛 13 頭を， 7 および 6 頭ずつの 2 群に分け， 1 番刚 りおよび 2 番刈り乾草だけを給与し，14 日間の代謝試 験を実施し，以下のような結果を得た。

1）乾物，有機物，細胞内容物および酸性デタージェ ント緎維の消化率は，1番刈りおよび 2 番朾り乾草の間 に有意な違いは認められなかった。

2）粗蛋白質，細胞壁物質およびへミセルロースの消 化率は, 1 番刈りより 2 番刈り乾草において高くなった.

3） エネルギーの消化率山, 乾物, 有機物, 細胞内容 物および粗蛋白質の消化率との間に有意な相関関係が認 められ，以下のような回帰式が得られた。

$$
\begin{aligned}
& \mathrm{GED}=0.93( \pm 0.16) \mathrm{DMD}+0.52, \mathrm{r}=0.858^{* *}, \\
& \mathrm{GED}=0.95( \pm 0.19) \mathrm{OMD}-2.94, \mathrm{r}=0.831^{* *}, \\
& \mathrm{GED}=0.31( \pm 0.08) \mathrm{CCD}+35.2, \mathrm{r}=0.745^{* *}, \\
& \mathrm{GED}=0.29( \pm 0.11) \mathrm{CPD}+36.8, \mathrm{r}=0.612^{*}, \\
& \text { ここで, GED はェネルギーの消化率, DMD, }
\end{aligned}
$$
$\mathrm{OMD}, \mathrm{CCD}$ おょび CPD はそれぞれ，乾物，有機物， 細胞内容物㧍よび粗蛋白質の消化率を表わす。

また，エネルギーの代謝率（q）と消化率（GED， \%) との間に以下の上うな回帰式が得られた。

$$
q=0.93( \pm 0.03) \mathrm{GED} / 100-0.04, \mathrm{r}=0.997^{* *}
$$

4）発育のための正味エネルギ一価は，1番刈乾草で, $0.73 \mathrm{MJ} / \mathrm{kg} \mathrm{DM}, 2$ 番刈乾草で, $1.28 \mathrm{MJ} / \mathrm{kg} \mathrm{DM}$ と 算定された。

日音会報，60（3）：286-291，1989 